\title{
Analysis of Early Reading Ability of Children in Group B of Kindergarten Tut Wuri Handayani Samahani Aceh Besar
}

\author{
Riza Oktariana, Maulinawati \\ riza@bbg.ac.id \\ Pendidikan Guru-Pendidikan Anak Usia Dini, Universitas Bina Bangsa Getsempena
}

\begin{abstract}
Abstrct
Reading is an activity of following a series of writings arranged in a linear manner. Experience is an important aspect of the reading process. Children who have a lot of experience will have a wider opportunity in developing an understanding of vocabulary in reading. The formulation of the problem in this study, what activities are done in training beginning reading skills in group B in TK Tut Wuri Handayani Samahani Aceh Besar. How is the description of beginning reading ability in group B in TK Tut Wuri Handayani Samahani Aceh Besar. What are the obstacles faced by teachers in teaching beginning reading skills to group B children in TK Tut Wuri Handayani Samahani Aceh Besar. The purpose of this study is to see a picture of the activities given to children in group B in TK Tut Wuri Handayani Samahani Aceh Besar. To see the beginning reading ability in group B children in TK Tut Wuri Handayani Samahani Aceh Besar. To find out the obstacles faced by teachers on the ability to read beginning in group B children in TK Tut Wuri Handayani Samahani Aceh Besar. The type of research is Qualitative research The instrument used is an interview, the sample size is 1 principal and 2 classroom teachers. The results show that beginning reading is very important for early childhood which will be the foundation of the beginning of reading. Teachers who teach at TK Tut Wuri Handayani Aceh Besar, are very understanding about the development of children's reading and also teachers at TK Tut Wuri Handayani Aceh Besar always encourage children by providing creative media that can attract children's attention in beginning reading so that teachers provide reading learning start by using a system of play while learning.
\end{abstract}

Keywords: Beginner, Reading, Early Childhood

(C) 2021 Riza Oktariana

This work is licensed under a Creative Commons Attribution-ShareAlike

\section{INTRODUCTION}

Early Childhood Education is an education provided for children before entering education at the Primary School level. Early childhood education is very important for children, as a preparation for the next level of education. Hasan (2009: 15) revealed that Early Childhood Education (PAUD) is a level of education before the level of basic education which is a coaching effort aimed at children from birth to 
six years old through the provision of educational stimuli to help physical growth and development. and spiritual so that the child has a readiness to enter further education.

Coaching efforts through early childhood education aimed at children need to be given so that later children can develop aspects of development that they have, one of which is the development of beginning reading. Through stimulation with learning activities aimed at helping the growth and development of children. According to Imas Kurniawan (2009: 13) reveals that "Growth is a change in size and shape of the body, and development is a mental change that takes place gradually and over a period of time".

Early childhood education, especially kindergarten (TK) is an important education as a container to build, grow, and develop all the potential of children optimally so that basic behavior and abilities are formed in accordance with the stage of development so that children have readiness to enter further education (Trianto, $2010: 24)$.

Based on the results of initial observations conducted by kindergarten in July 2020, it can be seen that the condition of children's beginning reading is very low, that is, from 16 children, there are 5 children who read well at the beginning, while 11 other children read at the beginning is still low. With the results of preliminary observations, the researchers want to conduct an analytical study on children's beginning reading in TK Tut Wuri Handayani Aceh Besar. Based on the above problems, the researcher took the title "Analysis of Early Reading Ability of Children in Group B Tk Tut Wuri Handayani Samahani Aceh Besar".

Based on the background of the problem on the formulation of the problem in this study are: 1 . What are the activities done in training beginning reading skills in group B in kindergarten Tut Wuri Handayani Samahani Aceh Besar ?, 2. What is the description of beginning reading ability in group B in kindergarten Tut Wuri Handayani Samahani Aceh Besar ?, 3. What are the obstacles faced by teachers in teaching beginning reading skills to children in group B in TK Tut Wuri Handayani Samahani Aceh Besar?.

\section{Understanding the Development of EarlyEarly}

Childhood is a child who is at a vulnerable age of 0-6 years (National Education Act 2013) and 0-8 years according to child education experts. According to Mansur (2015: 88) early childhood is a group of children who are in the process of growth and development that is unique. They have a specific pattern of growth and development according to their level of growth and development. Maleong mentioned that the variety of education for early childhood non-formal pathways are divided into three groups, namely the group of childcare parks (TPA) aged 0-6 years); play group (KB) ages 2-6 years; group of similar PADU unit (SPS) age 0-6 years (Aaron, 2010: 43).

From the above description, the authors conclude that early childhood is a child in the age range of 0-6 years who are experiencing very rapid growth and development, so it needs proper stimulation to grow and develop to the maximum. The provision of such stimulation should be provided through the family environment, non -formal early childhood education such as childcare centers (TPA) 
or play groups $(\mathrm{KB})$ and formal early childhood education such as kindergarten and RA.

\section{General Characteristics of Early Children 5-6 Years Old}

Children 5-6 years old 1). More controlled movement 2). Language development is good enough 3). Able to play and make friends 4). Sensitive to social situations 5). Knowing gender differences and status 6). Can count from 1-10. Based on the characteristics that have been presented, it can be seen that children aged 5-6 years (group B), they can perform coordinated movements, language development is good and able to interact socially. This age is also a sensitive time for children to learn the language. With good movement coordination, the child is able to move the eyes and hands to realize his imagination into the form of a picture, so that the use of pictures of the child's work can help improve the child's speaking ability.

\section{Beginning Reading Ability}

Many differences of opinion about allowed/not allowed to teach beginning reading to children in group $B$, the author agrees with the theory of experts who are allowed to read in early childhood who said it is allowed to read and count in early childhood children according to Sabarti theory, ( 2012: 42) who stated that the beginning Reading is emphasized on "voicing" the sentences presented in written form. In other words, young children are required to be able to translate written form into oral form. In this case, the aspect of fluency in reading spelling is also included.

The subphase of symbolic function occurs at the age of 5-6 years. By this time, the child has the ability to describe an object that is not physically present. This ability allows the child to use small blocks to build houses, assemble puzzles, and other activities. By this time, the child is already able to draw humans in a simple way. The subphase of egocentric thinking occurs at the age of 2-4 years. Egocentric thinking is characterized by a child's inability to understand the perspectives or ways of thinking of others. True or false, for the child in this phase, is determined by his own point of view which is called egocentric.

\section{RESEARCH METHODOLOGY}

This research uses a qualitative research approach where qualitative research as a scientific method is often used and implemented by a group of researchers in the field of social sciences, including education. A number of reasons are given in essence that qualitative research enriches the results of quantitative research. Qualitative research is conducted to build knowledge through understanding and discovery. Qualitative research approach is a process of research and understanding based on methods that investigate a social phenomenon and human problems. In this study, the researcher makes a complex picture, examines the words, a detailed report from the views of the respondents and conducts a study on natural situations (Iskandar, 2009).

This research was conducted in August 2020 in the second semester of the academic year 2020. The research was located at Jalan Lam Ara Tunong No. 21 Samahani District, Aceh Besar Regency. The sample is part of the number and characteristics possessed by the population, or a small part of the population members taken according to certain procedures so that it can represent the 
population, which is the sample in this study is teachers in TK Tut Wuri Handayani Samahani Aceh Besar as many as 2 teachers and 1 principal.

\section{Data Collection Techniques}

In this study, data collection techniques and instruments that will be used, among others:

a) Interview. Interviews in this study used in -depth interviews. An interview is a conversation with a specific purpose. The conversation was conducted by two parties, namely the interviewer who asked the question and the interviewee who provided the answer to the question Moleong (2009).

b) Documentation. Sukardi (2011: 81) states that documentation is a way to obtain data from various written sources or documents that exist in the respondent or the place where they conduct daily activities. Documentation in this study is used as a complementary source of data, because many things must be a source of data that can be used to test, interpret, even predict or predict events during the study. Analysis of this documentation will be very helpful to complete and deepen the results of observations. Thus it is necessary to document to complete the research and obtain a picture of what is happening in each event.

\section{Data Analysis Techniques Data}

Analysis is the process of simplifying data into a form that is easier to read and interpret. In this qualitative research using abstractive comparative logic analysis that is a logic that uses the method of comparison. conceptualization, categorization and description are developed on the basis of incidence (incidence) obtained when field activities take place Boengin (2011). The analysis of this research is done continuously from the beginning of the study and then throughout the study.

So since obtaining data from the field either from observations, interviews or documentation directly studied and summarized, analyzed and analyzed until the end of the study. Furthermore, the data analysis flow that the author uses is:

The steps of data analysis can be described as follows:

\section{Data Collection}

To facilitate in obtaining the data needed in this study, researchers need to use data collection techniques such as interviews and documentation.

\section{Data reduction (data reduction)}

Reducing data means summarizing, choosing the main things, focusing on the important things, looking for themes and patterns and discarding unnecessary thus the data that has been reduced will give a clearer picture and will make it easier. in performing further data collection.

\section{Data display}

In qualitative research, data presentation can be done in the form of brief descriptions, charts, relationships between categories and the like.

\section{Withdrawal of conclusions (verification)}

The next step is the withdrawal of conclusions, the initial conclusions presented are still temporary and will change if no strong evidence is found to support the next stage of data collection. But if the conclusions presented at an early 
stage are supported by valid and consistent evidence when the researcher returns to the field while collecting data then the conclusions presented are credible conclusions.

Thus the conclusion may be able to answer the problem formulation but may also not because in qualitative research the problem formulation is still temporary and will develop after the research is in the field. Thus the work of collecting data for qualitative research should be directly followed by the work of writing, editing, classifying, reducing, and presenting data, as well as drawing conclusions by comparing as qualitative data analysis. In qualitative research generally looks more at the process than the product of the object of research. In addition, the conclusions from the qualitative data are not in the form of numbers but are presented in the form of verbal words whose processing ranges from editing to presenting in a concise manner is done in the field.

\section{RESEARCH RESULTS \\ Research Findings Data}

Before conducting the study, researchers found some data on children's reading ability in group B in TK Tut Wuri Handayani Aceh Besar. Researchers found that the condition of children's beginning reading is very low, that is, out of 16 children there are 5 children who read the beginning well, while 11 other children read the beginning is still low. With the results of preliminary observations, the researchers want to conduct an analytical study on children's beginning reading in TK Tut Wuri Handayani Aceh Besar.

Activities Carried Out in Training Beginner Reading Ability in Kindergarten Tut Wuri Handayani

Teachers in Kindergarten Tut Wuri Handayani Aceh Besar, performed several treatments on children in training children's beginning reading ability.

There are several methods provided by teachers such as:

\section{Method of Introducing Letters with Letter Card Media}

In the use of this method, the teacher performs the steps in playing letter cards, including by showing one by one the letter cards alternately. The child observes the letter symbols on the card being held, then the child says the letter symbols on the letter card, then the child connects each letter card into syllables. The steps to introduce the letters performed by teachers in TK tut Wuri Handayani Aceh Besar are:

1. The child was conditioned to sit in a circle on the carpet.

2. The children were given an explanation of the game to be played, which was a letter card game.

a. Children are given examples of how to play letter cards which will be explained as follows:

1. The teacher takes a letter card, then shows it to the children.

2. The teacher pronounces the letter symbols on the letter cards, and then the children are given the opportunity to imitate the pronunciation of the letter symbols.

3. The teacher turns the letter card over, then mentions the picture on the letter 
card and then mentions the front letter as well, and the children are also given the opportunity to imitate, say.

b. The children were asked to practice a letter card game together, with the child still sitting in a circle.

c. After the children play together, the teacher gives each child the opportunity to play a letter card game individually, the game begins:

1. The child takes a letter card, the child observes the letter card and then the child says the letter symbol written on the letter card.

2. The child turns over the letter card, the child observes the picture on the card and then the child says the first letter of the name of the picture on the letter card.

\section{Word Card Game Method}

In addition to using letter cards, teachers at TK Tut Wuri Handayani also use word cards to train children's beginning reading skills. The function of letter cards is to recognize letters to children, while the function of word cards is to recognize the combination of letters into syllables that will be read by the child.

The steps taken by teachers in training children's beginning reading skills in TK Tut Wuri Handayani are as follows:

a. The teacher asked some words related to body hygiene activities to the class in general. For each word the child says, the teacher sticks the word card on the flannel board, then asks the child to repeat the word together.

b. Variations in pronouncing words can be made, for example by asking the whole class, asking some students to read, or asking students how to read them.

c. This activity is done until all the words related to the theme that have been prepared can be pasted on the flannel board.

d. Next, the teacher asked the students to practice reading the words on the flannel board in their hearts, for about 10 minutes. Those who do not yet know how to read it can ask the friend next to him.

e. The teacher can give the task to some students to choose some words that are attached, then find the pair that is the syllable card. These syllable cards are placed under the word cards, and students read them aloud

f. The teacher divides the students in the class into several groups. Each group finds another group as a play partner.

g. One group takes two or three words from the ones on the board, then the other group makes a sentence based on the words chosen by the other group.

h. It must be ensured that each group takes a turn choosing a word card and making a sentence based on the selected word card.

Teachers who teach at TK Tut Wuri Handayani use these two methods in training students' beginning reading ability, so that children's beginning reading ability becomes better, in addition, teachers at TK Tut Wuri Handayani have creativity in teaching their students.

\section{Description of Beginning Reading Ability in TK Tut Wuri Handayani Aceh Besar.}



Besar

Children- children in kindergarten Tut Rezky Aceh Besar have the ability to read different starting each child with other children. Especially in group B children consisting of 16 children, there are 5 children who read it at the beginning well, while 11 other children read the beginning is still low. This can be seen when the teacher provides literacy lessons to be arranged into a sentence, 11 children among them are not able to compose letter cards into a simple sentence.

\section{Obstacles Faced by Teachers in Teaching Beginning Reading in TK Tut Wuri Handayani Aceh Besar.}

Obstacles faced by teachers, lie in the condition of different children, each child has different abilities from one child to another, so the teacher must know the composition of beginning reading learning for each child by providing learning according to ability son.

In addition, when teaching there are still some children who do not want to follow the lessons given by the teacher. So that teachers must be more creative in dealing with children so that children can be enthusiastic in following the learning.

Based on the results of the interview with the principal above, it can be concluded that the teachers who teach at TK Tut Wuri Handayani understand the development of children's reading, the use of media is given in accordance with the needs of children. The use of learning media provided by the teacher can attract the child's attention so that the child is enthusiastic and interested in learning to read. It can be said that in TK Tut Wuri Handayani, the teachers who teach in group B have their own knowledge and ways of training children's reading skills very well.

Based on the results of an interview with Mrs. Adian S.Pd, stated that reading the beginning is very important given to children at an early age, and the ability to read the beginning of children certainly differ from one child to another, so teachers use media that can attract children's attention in reading the beginning. Obstacles faced by teachers lie in the ability to read the beginnings of each child, there are children who can read quickly and there are also children who are slow in responding to the beginning reading learning given by the teacher. In addition the teacher teaches the spelling of the letters by giving the prefix letters that are exemplified on animals and fruits so that the child will think to find what conjunction word matches the prefix letter given by the teacher. Thus it can be concluded that teacher 1 provides appropriate and effective learning on the development of children's beginning reading in TK Tut Wuri Handayani Aceh Besar.

Based on the results of the interview with Mrs. Nurmaya Sofa above, stated that it is very important to read this beginning given to children at an early age, especially in group B, where children will enter the primary school level where reading learning will be done at a higher level. In addition, there are some obstacles faced by teachers such as the lack of educational toys that can attract children's attention to learning to read the beginning and also the role of parents in the ability to read the beginning of children is only focused in school. As for the activities carried out by the teacher in developing the child's beginning reading ability is very well done by the teacher by creating a creative media so that the child becomes interested in learning to read beginning.

Thus it can be concluded that the beginning reading learning given to children in TK Tut Wuri Handayani is very good and appropriate and can develop the ability to read the beginning. 


\section{CONCLUSION}

Afterresearch on the analysis of beginning reading ability in TK Tut Wuri Handayani Aceh Besar through the results of interviews with 1 principal and 2 teachers group B showed that beginning reading is very important for early childhood which will be the initial foundation in reading. Teachers who teach at TK Tut Wuri Handayani Aceh Besar, are very understanding about the development of children's reading and also teachers - teachers at TK Tut Wuri Handayani Aceh Besar always encourage children by providing creative media that can attract children's attention in beginning reading so that teachers provide reading learning start by using a system of play while learning.

The beginning reading learning given to children at TK Tut Wuri Handayani is very good and accurate and can develop the ability to read the beginning. So that children who graduated from TK Tut Wuri Handayani can read well when entering the primary school education level.

Then there are some suggestions in this study, among them is that teachers are expected to focus on paying attention to children when at school by providing learning in accordance with the learning character of each child. Parents can also focus on understanding the child when learning at home by providing a comfortable atmosphere for the child in accordance with the character of learning. In this study there are several things to consider such as: before conducting the interview is preferred to ask the child's news, and also pay attention to the child's comfort by asking slowly.

\section{ACKNOWLEDGMENTS}

We would like to thank all those who have helped in completing the research we did, especially to the school that is willing to provide data in accordance with the research instruments that we designed. Further thanks also to the Journal of Childhood Development which has received and published our research.

\section{REFERENCES}

Anderson. 2018. Membaca Permulaan Pada anak usia Dini. Cetakan ketiha belas, Bandung.

Burhan Nurgiyantoro. 2010. Pengajaran Pengatuhan Membaca Permulaan. Gramedia Jakarta.

Cachrane Efal. 2018. Perkembangan Membaca Pada Anak Usia Dini. Cetakan ketiha Bandung.

Ernawulan Syaodih. 2015. Perkembangan Membaca Permulan Anak. Penerbit Universitas terbuka.

Masri Sareb. 2018. Kemampuan Membaca Permulaan. Penerbit Universitas terbuka. Mallquist. 2011. Materi Pengenalan Membaca Permulaan. Universitas Swasta.

Maimunah Hasan. 2011. Pendidikan Anak Usia Dini dalam Mengeja huruf. Yogyakarta: Pustaka Pelajar.

Muyono. A . 2013. Perkembangan Membaca Anak Usia Dini Yogyakarta: Diva Press.

Partini. (2010). Pengantar Pendidikan Anak Usia Dini. Yogyakarta: Grafindo Litera 
Analysis of Early Reading Ability of Children in Group B of Kindergarten Tut Wuri Handayani Samahani Aceh Besar

Media.

Reni Akbar Hawadi. 2011. Berbahasa Pada Anak Usia Dini. Universitas terbuka Steinberg . 2011. Kemampuan Membaca Permulaan. Penerbit Universitas terbuka. Santrock . 2012. Materi Pengenalan Membaca Permulaan. Universitas Swasta.

Slamet Suyanto. 2015. Pengantar Pendidikan Anak Usia Dini. Gramedia. Jakarta Sofia Hartati. 2015. Pendidikan Anak Usia Dini . Yogyakarta: Pustaka Pelajar. Torrey. 2011. Prinsip-prinsip Membaca Permulaan. Penerbit Universitas terbuka. 